\title{
Advanced Methods for Photovoltaic Output Power Forecasting: A Review
}

\author{
Adel Mellit ${ }^{1}$, Alessandro Massi Pavan ${ }^{2, *}$, Emanuele Ogliari ${ }^{3}{ }^{(}$, Sonia Leva ${ }^{3}{ }^{(-)}$and Vanni Lughi ${ }^{2}$ \\ 1 RELab, University of Jijel, Jijel 18000, Algeria; adelmellit2013@gmail.com \\ 2 Dipartimento di Ingegneria e Architettura, University of Trieste, 34127 Trieste, Italy; vlughi@units.it \\ 3 Department of Energy, Politecnico di Milano, 20156 Milano, Italy; emanuelegiovanni.ogliari@polimi.it (E.O.); \\ sonia.leva@polimi.it (S.L.) \\ * Correspondence: apavan@units.it
}

Received: 13 November 2019; Accepted: 30 December 2019; Published: 9 January 2020

\begin{abstract}
Forecasting is a crucial task for successfully integrating photovoltaic (PV) output power into the grid. The design of accurate photovoltaic output forecasters remains a challenging issue, particularly for multistep-ahead prediction. Accurate PV output power forecasting is critical in a number of applications, such as micro-grids (MGs), energy optimization and management, PV integrated in smart buildings, and electrical vehicle chartering. Over the last decade, a vast literature has been produced on this topic, investigating numerical and probabilistic methods, physical models, and artificial intelligence (AI) techniques. This paper aims at providing a complete and critical review on the recent applications of AI techniques; we will focus particularly on machine learning (ML), deep learning (DL), and hybrid methods, as these branches of AI are becoming increasingly attractive. Special attention will be paid to the recent development of the application of DL, as well as to the future trends in this topic.
\end{abstract}

Keywords: photovoltaic plant; power forecasting; artificial intelligence techniques; machine learning; deep learning

\section{Introduction}

Over the last decade, a rapid growth of the photovoltaic (PV) market has been observed worldwide, and according to the International Energy Agency (IEA) the global PV capacity exceeds $500 \mathrm{GW}_{\mathrm{p}}$ [1].

As the PV produced power depends on the weather conditions that are by nature highly uncertain [2], the penetration of such systems in the actual power system asset represents a challenge [3]. The power produced by the PV plants depends on a number of meteorological variables such as solar irradiance, air temperature, cloud variation, wind speed, relative humidity, etc. PV output power forecasting is a challenge in particular in the case of multi-step applications, large databases, noisy measurements, and multiple input-output observations. On the other hand, reliable forecasts allow avoiding penalties to plant managers caused by deviations between the scheduled and the produced power [4]. The forecast accuracy is generally improved by a pre-processing and a post processing of historical and forecasted PV output power [5].

In the literature, numerous PV power forecasting methods have been developed and, with reference to the forecast horizon [6], these can be divided into four types. Very short-term forecasting with a time horizon ranging from a few seconds to some minutes; short-term forecasting up to $48-72 \mathrm{~h}$ ahead; medium-term forecasting from a few days to one week ahead; long-term forecasting from a few months to a year or more. Each forecasting horizon has its specific application so that, for example, very short-term forecasters are used for the control and management of PV systems, in the electricity market, for the control of microgrid, etc. Short-term horizons are adopted for the control of power 
system operations, economic dispatch, unit commitment, etc. Medium and long-terms horizon are usually used for the maintenance and the planning of PV plants.

Another classification considers one and multi-step-ahead forecasters, and these latter are more prevalent in many applications. With regards to multi-step forecasting, there are three main strategies: the multi-input multi-output strategy, the recursive strategy, and the direct strategy [7].

The major factors that affect the performance of the forecasters used in the prediction of the power produced by PV plants are [8]: the time-horizon and time resolution, the weather conditions, the geographic location, and the availability and quality of the data.

With reference to these parameters, different forecasters can be chosen for the particular need: physical methods $[9,10]$ that are mainly based on the use of numerical weather prediction (NWP) models [11,12] or satellite images [13] which can be used for developing regional models. In this case, meteorological data from satellite images are often used for long-term forecasting [3]. NWP models are widely used to predict the state of atmosphere up to 15-days ahead [14], and do not need any historical data. These methods can provide a good accuracy, but depend mainly on the stability of the weather conditions. However, the implementation of physical models is in general relatively difficult, as they require a number of parameters and expensive equipment that are not always available in many areas of the world. In addition, for most of the available NWP the first hours of predictions are not particularly useful for solar forecasting [15].

Another option is statistical and probabilistic approaches. These methods include regression models [16], exponential smoothing, autoregressive models (AR), autoregressive moving integrated average (ARIMA), [17], time series ensemble [18], and probabilistic approaches [19-21]. Statistical approaches are more suitable for short-term forecasting up to one day-ahead. To cope with the problem of non-linearity several attempts were done, for example an extended application of seasonal time series ensemble for PV forecasting can be found in [18].

Advanced methods based on artificial intelligence (AI) techniques and machine learning (ML) [22] include artificial neural networks (ANNs), k nearest neighbor ( $\mathrm{kNN}$ ), extreme learning machine (ELM), support vector machine (SVM), etc. These methods, that do not need any information regarding the PV systems, have some advantages typical of statistical approaches. They are used when measurements from the field are available, and basically for short-term applications [23].

Hybrid approaches combine one of the above-mentioned advanced methods with one physical or statistical approach. This type of techniques presents a very good forecasting accuracy as they benefit from the combination of two well performing techniques [24,25].

In the literature, there are models based on the use of on-site measurements, models relying on weather forecast data, and models that combine on-site historical measurements with weather forecasts [8]. The latter are more and more used and belong to the hybrid category.

There are a good number of reviews on PV power, and the most recent ones are reported in Table 1. The present work differs from the ones already available in the literature, as the main objective in this case is to review the field of advanced techniques. This review offers the first comprehensive comparison of the most relevant techniques for PV power forecasting base on machine learning (ML), deep learning (DL), and hybrid methods. These methods are validated with external data (data not used in model development) to verify the capability of the model to forecast power with good accuracy, when it is mentioned in the referenced papers. 
Table 1. Review papers on photovoltaic (PV) power forecasting.

\begin{tabular}{|c|c|c|c|}
\hline Ref & Year & Authors & Major Findings \\
\hline [23] & 2008 & Mellit and Kalogirou & $\begin{array}{l}\text { This review is on a number of the first forecaster's techniques using ANNs for the forecasting of the power } \\
\text { produced by PV systems. It was shown that AI based techniques have a great potential in the estimation, and } \\
\text { recurrent neural networks-based (RNNs) were recognized as the most accurate forecasters. Also, long-short term } \\
\text { memory (LSTM) had been widely used. }\end{array}$ \\
\hline [4] & 2016 & Antonanzas et al. & $\begin{array}{l}\text { This paper includes regression techniques and AI-based methods. Authors found out that statistical approaches } \\
\text { perform better than parametric approaches. They also mentioned that most recent techniques are based on the use } \\
\text { of ML methods (including SVM, ELM, LSRV, FL, etc.), due to the easiness of modeling without the need to know } \\
\text { the PV plant characteristics. }\end{array}$ \\
\hline [5] & 2016 & Raza et al. & $\begin{array}{l}\text { The authors provided a complete review including time series, ANNs, and some hybrid approaches. A comparison } \\
\text { between ANN-based and classical time series models was also presented. The conclusions were that the forecast } \\
\text { accuracy con be enhanced by pre and post-processing the historical data. ANNs gave better performances than } \\
\text { other classical time series approaches. }\end{array}$ \\
\hline [26] & 2017 & Barbieri et al. & $\begin{array}{l}\text { The authors wrote that the methods based on the forecasting of solar irradiance and cell temperature are the best } \\
\text { forecasting approaches when there are rapid fluctuations in the PV power (especially occurring with a sky partially } \\
\text { clouded). They also observed that a combination of satellite and land-based sky imaging improve the forecasting } \\
\text { results in the case of very short forecasting. }\end{array}$ \\
\hline [27] & 2017 & Ogliari et al. & $\begin{array}{l}\text { The authors presented an extended comparative study between physical and hybrid methods. The conclusion was } \\
\text { that the physical-hybrid-artificial neural networks (PHANN) always show the highest accuracy. }\end{array}$ \\
\hline [28] & 2018 & Das et al. & $\begin{array}{l}\text { In this work, a general review on recent studies on the direct forecasting methods was conducted. The authors } \\
\text { pointed out that ANN and SVM-based forecasting models perform particularly well under rapid and varying } \\
\text { environmental conditions. Optimized algorithm can significantly increase the forecasting accuracy, and genetic } \\
\text { algorithms (GA) represent one of the most practical optimization techniques for the forecasting of PV power. }\end{array}$ \\
\hline [29] & 2018 & Sobri et al. & $\begin{array}{l}\text { The main conclusion of this review was that ANN and SVM-based methods are widely used due to their ability in } \\
\text { solving complex and non-linear forecasting problems. Ensemble methods were found capable to improve the } \\
\text { forecasting accuracy as they're able to merge linear and non-linear methods. }\end{array}$ \\
\hline [30] & 2019 & Naveed Akhter et al. & $\begin{array}{l}\text { A review on ML and metaheuristics methods for solar radiation and PV power forecasting has been presented in } \\
\text { this work. The authors reported that hybrid models based on ML and metaheuristic methods could contribute to } \\
\text { improve the forecasting accuracy, while GA-based techniques represent the most viable optimization method [28] }\end{array}$ \\
\hline
\end{tabular}


The paper is organized as follows: a brief introduction about artificial intelligence techniques, including machine learning and deep leaning is provided in Section 2; Section 3 presents the recent applications of AI techniques in PV power forecasting; concluding remarks and future directions will be provided in the last section.

\section{Artificial Intelligence Techniques}

There are many definitions of artificial intelligence and one of the most used is "imitating intelligent human behavior" that includes systems with the following characteristics: they have a "thinking process" similar to the one human beings have, they are able to act like humans, their thinking process is rational, and their acting is rational too. For these reasons a number of intelligent computing technologies are today more and more used as an alternative to conventional techniques [22].

There are different branches of AI techniques that can be classified as follows [31]: machine learning (ML) including supervised, unsupervised, reinforcement learning which regards algorithms/statistical models that computer systems use in order to effectively perform a specific task without using explicit instructions, and deep learning (DL) which is seen as a ML subset. DL allows computational models that are composed of multiple processing layers to learn representations of data with multiple levels of abstraction.

Other branches are expert systems (ESs), which allow computers to "make decisions" by interpreting data and selecting from a list of alternatives, computational intelligence (CI) covering the theory, and development of biologically and linguistically motivated computational paradigms (the main three pillars of CI are: artificial neural networks (ANNs), genetic algorithms (GAs), and fuzzy $\operatorname{logic}(\mathrm{FL})$ ).

These main groups often are adopted in order to accomplish specific tasks or are widely used in many fields crosswise such as: problem solving and planning (PSP), nonmonotonic reasoning (NMR), logic programming (LP), pattern recognition (PR), knowledge representation (KP), Common sense knowledge and reasoning (CSKR), natural language processing (NLP), computer vision (CV), robotics, epistemology, ontology, and others.

Some of the techniques used in the literature for the forecasting of the PV power are [23]: GA including different meta-heuristic methods such as particle swarm optimization (SWO), ACO, and etc.; ML including support vector machine (SVM), k-nearest neighbors (k-NN), linear regression (LR), decisions trees (DT), naïve Bayes (NB), and etc.; NNs including MLP, RNN, RBFN, etc.; FL and hybrid systems that combine two or more branch of AI (such as for example ANFIS, ANN-GA, etc.

This review paper focuses on the most used AI techniques for the PV output power forecasting that are ML and DL that, as shown in Figure 1, are a subset of AI. With reference to AI, the next breakthrough in the field of PV forecasting will come from systems that combine representation learning and complex reasoning [32].

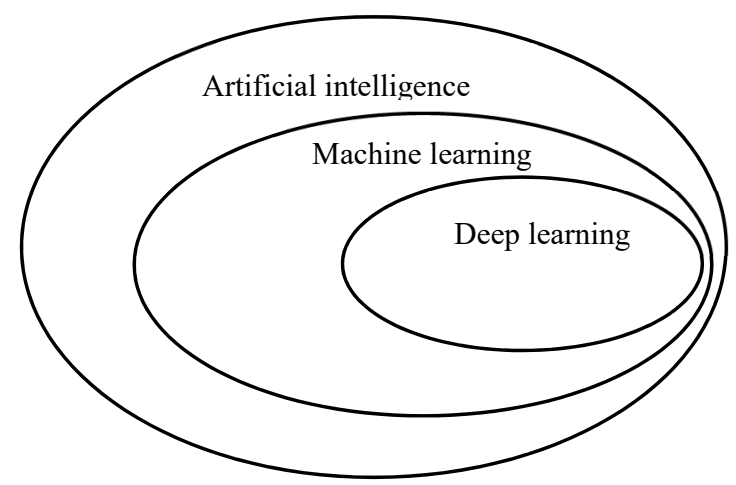

Figure 1. A Venn-diagram of artificial intelligence: link between artificial intelligence, machine learning and deep learning. 


\subsection{Machine Learning}

According to Arthur Samuel (1959) [33], ML refers to techniques able to give computers the ability to learn automatically from experience (i.e., dataset) without being explicitly programmed by human beings. ML algorithms can be classified into three major algorithms [34,35]: supervised learning, unsupervised learning, and reinforcement learning. In the first case, an algorithm tries to create some relationships and dependencies between input and output features. In the case of unsupervised learning, there is no output and the algorithm searches for rules and patterns in the available dataset in order to better describe the data. The reinforcement type is mainly used to bring high dimensional into lower dimensional data for visualization or analysis purposes. This type of learning can be also divided into the following two kinds of problems: clustering and association.

\subsection{Deep Learning}

Deep learning can be defined as providing knowledge to computers through data, observations and interactions with the world [36]. DL is a relatively new advancement in NN programming and represents a way to train deep neural networks (DNNs), as traditional NN-based methods might be affected by problems such as overfitting, diminishing gradients, etc. [36]. As defined in [35], a NN is a massively parallel-distributed processor made up of simple processing units that has a natural propensity for storing experiential knowledge and making it available for use. A typical NN comprises several layers of interconnected neurons, each one connected to the others in the ensuing layer. Data are presented to the neural network via an input layer, while an output layer holds the response of the network to the input. One or more hidden layers may exist between the input layer and the output layer. Essentially, any NN with more than two layers is called "deep". On the other hand, DL is a semi-supervised training approach, suitable for DNN training [36].

In the last few years, DL has led to very good performance on a variety of problems, such as speech recognition, visual recognition, natural language processing, pattern recognition, automatic translations, self-driving cars, medical diagnosis, financial prediction, automatic trading, etc. On the contrary, the application of DL in photovoltaics is still limited. DNNs are able to automatically learn arbitrary complex mappings from inputs to outputs and support multiple inputs and outputs [36]. The main DL methods are [32]: convolutional neural network (CNN), long short-term memory (LSTM), and other hybrid combinations especially used when dealing with multistep forecasting.

CNNs have a grid-like topology and are a special type of NNs where the convolution is used in place of a general matrix multiplication [37]. Like common NNs, CNNs are made of an input layer, an output layer, and many hidden layers in between. The hidden layers consist of three layers: the convolution, the activation or rectified linear unit (ReLU) layer, and the pooling layer. The ability of CNNs to learn and automatically extract features from raw input data can be applied to time series forecasting problems. A sequence of observations can be treated like a one-dimensional image that a $\mathrm{CNN}$ model can read and distill into the most salient elements.

LSTM is a kind of RNN with a memory cell, an input gate, an output gate, and a forget gate in addition to the hidden state always present in traditional RNNs. The main drawback of RNNs is that they practically fail to handle long-term dependencies. As the gap between the output and the input data point increases, RNNs fail in connecting the information between the two. In the last decades, researchers have proposed a number of new recurrent units (RU) to solve this problem, and the most effective solution are LSTM [38] and gated recurrent units (GRU) [39].

\section{AI-Based Techniques Used for PV Output Power Forecasting}

This section describes the most advanced ML and DL-based techniques used in PV output forecasting. With reference to Figure 2 (where papers published in journals between 2010 and 2019 have been considered), the most popular methods use a ML approach (55\%) followed by hybrid methods 
used (36\%). Among DL techniques, ANN-based methods including MLP, RNN, and RBF are the most used $(48 \%)$.

(a)

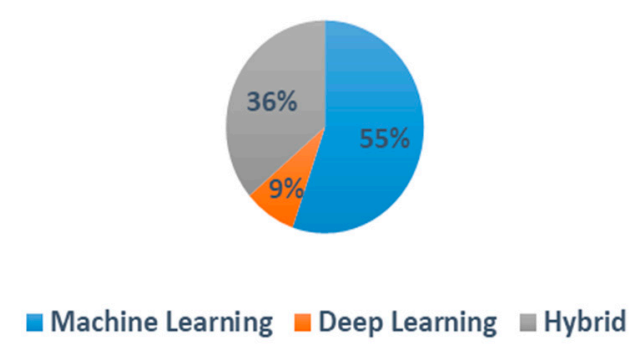

(c)

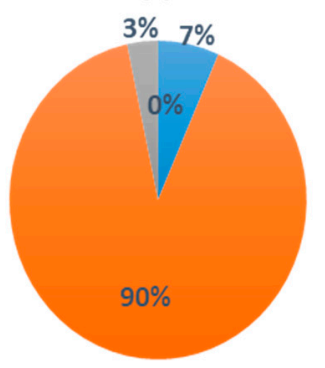

- Very short-term $\|$ short-term

Medium term L Long-term (b)

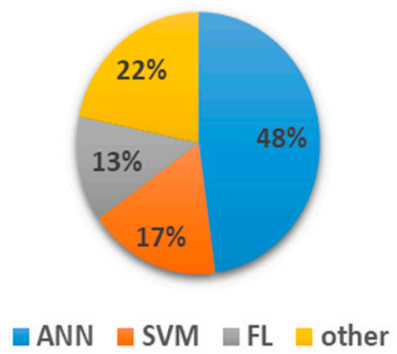

(d)

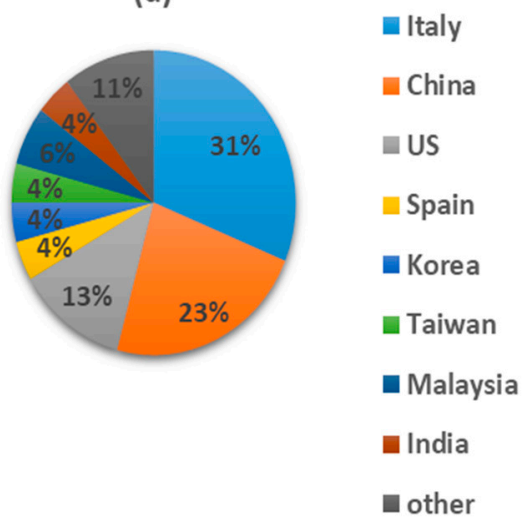

Figure 2. (a) AI-based PV power forecasting method; (b) the most common deep learning (DL)-techniques; (c) investigated time scale horizons, and (d) countries involved in PV forecasting.

Finally, long-term prediction is certainly the most investigated field $(90 \%)$, and the Italian scholars are the most committed in this area of research.

In the last few decades, one-step ahead forecasters were the most common, while during the last years due to the progress achieved in the soft-computing techniques and data analysis, multi-step forecast methods are becoming more and more attractive.

With reference to ML and DL methods, there are mainly three approaches and methods:

- Methods that use only historical output powers record (on site measurement) [40]:

$$
\left(p_{t}, p_{t+1}, . ., p_{t+k}\right)=f\left(p_{t-n}, p_{t-n-1}, p_{t-n-2}, \ldots p_{t-1}\right)
$$

where $p_{t}$ is the actual power, $p_{t-n}$ is the previous power, $p_{t+k}$ is the forecasted power at step $k$, and $f$ is a functional dependency between past and future. $t \in\{1, . ., n\}, n$ is the length of the measurements.

- Methods that rely upon forecasted meteorological parameters such as solar irradiance, air temperature, relative humidity, cloud index, wind speed, pressure, etc. These parameters can be from satellite images, numerical weather prediction models, or statistical models:

$$
\left(p_{t}, p_{t+1}, \ldots, p_{t+k}\right)=f\left(G_{t+k}, T_{t+k}, W S_{t+k}, R H_{t+k}, C_{t+k} \ldots\right)
$$

where $G_{t+k}, T_{t+k}, W S_{t+k}, R H_{t+k}$, and $C_{t+k}$ are the forecasted solar irradiance, air temperature, wind speed, relative humidity, and cloud cover respectively. 
- Methods which combine the use of historical power data records with meteorological parameters forecasts:

$$
\left(p_{t}, p_{t+1}, . ., p_{t+k}\right)=f\left(p_{t-n}, p_{t+n-1}, . ., p_{t-1}, G_{t+k}, T_{t+k}, W S_{t+k}, R H_{t+k}, C_{t+k} \ldots\right)
$$

These methods can be used both for one-step and multistep ahead forecasting.

\subsection{Application of Machine Learning in PV Power Forecasting}

With reference to the period 2011-2019, a comprehensive summary of the most relevant researches dealing with the applications of ML-based methods in the field of PV power forecasting is reported in Table 2.

An indirect method to estimate the power produced by a PV plant 24-h ahead has been described in [41]. The method uses as an input the forecasted solar irradiance and is based on a simple multi-layer perceptron neural network (MLP). The mean absolute error (MAE) is lower than $5 \%$ for all examined case studies. A conclusion of this work was that using more input parameters such as cloud cover, pressure, and wind speed could improve the model accuracy. The same happens when the quality and the size of the database are improved.

A RBF-NN for a 24-h ahead online PV power forecasting is shown in [42]. In this work, a self-organized map (SOM) is utilized in order to classify the input variables. The developed model accepts as an input the mean daily values of solar irradiance, temperature, wind speed, and historical powers. The performance of this model is represented by a MAPE of $8.3 \%$ corresponding to sunny days, and a $54.4 \%$ corresponding to rainy days. The model was tested for a small-scale $28 \mathrm{kWp} \mathrm{PV}$ plant installed at Huazhong, China.

In [43] the authors described a method for a one-day ahead PV power output forecasting. The method based on SVM technique works with a weather classification, accepts as an input the historical dataset of power together with the weather forecasts for the next day. Four models have been developed corresponding to four typical days: cloudy, foggy, rainy, and sunny. The average MRE was $8.64 \%$, while the best results have been achieved for sunny days (in this case the MAE was $4.85 \%$ ).

A short-term ANN-based forecaster is described in [44]. In this case, the input data were the historical electrical energy generation and the weather forecasts coming from a NWP model. The MLP-NWP performed better than other investigated ARIMA and K-NN, while ANFIS, MLP-NWP based-models outperformed all the tested forecasters. Considering different forecasting horizons from 16-39 $\mathrm{h}$, the average root mean squared error (RMSE) was $11.79 \%$, while the average MAE was $6.41 \%$.

In [45] the authors developed a simple NN for the short medium-term forecasting of the power produced by a PV small-scale plant installed in Istanbul, Turkey. In this case, only the historical powers have been used to design and verify the model that works well only for a time horizon in the range [5-40 min]. A support vector regression (SVR)-based method is used for the power of a $1 \mathrm{MWp}$ plant installed at Kitakyushu, Japan [46]. The model accepts as an input different the cloudiness level, the relative humidity, and the extraterrestrial insolation. The obtained results are represented by an RMSE corresponding to $0.0948 \mathrm{MWh}$, and the model has shown bad performances in the case of partially clouded days. The authors claimed that there is no need to use relative humidity and air temperature as an input of the model. 
Table 2. Machine learning (ML)-based methods for the forecast of PV power-period 2010-2019.

\begin{tabular}{|c|c|c|c|c|c|c|c|}
\hline Ref and Authors. & Year & Method & $\begin{array}{l}\text { Time Horizon and } \\
\text { Resolution }\end{array}$ & Parameters Used & $\begin{array}{l}\text { Point or Regional } \\
\text { Forecast }\end{array}$ & $\begin{array}{l}\text { Region and PV } \\
\text { Nominal Power }\end{array}$ & Accuracy \\
\hline $\begin{array}{c}\text { [41] } \\
\text { Mellit and Massi Pavan }\end{array}$ & 2010 & ANN & $\begin{array}{l}24 \mathrm{~h} \text { ahead } \\
5 \mathrm{~min}\end{array}$ & $\begin{array}{l}\text { Meteorological parameters: } \\
\text { forecasted solar irradiance and } \\
\text { air temperature }\end{array}$ & 1 point & $\begin{array}{l}\text { Trieste, Italy } \\
120 \mathrm{kWp}\end{array}$ & $\mathrm{MAE}<5 \%$ \\
\hline $\begin{array}{c}\text { [42] } \\
\text { Chen et al. }\end{array}$ & 2011 & ANN & $\begin{array}{l}24 \mathrm{~h} \text { ahead } \\
5 \mathrm{~min}\end{array}$ & $\begin{array}{l}\text { Historical powers and } \\
\text { meteorological forecast }\end{array}$ & 1 point & $\begin{array}{l}\text { Huazhong, China } \\
28 \mathrm{kWp}\end{array}$ & $\begin{array}{l}\text { MAPE: } 8.29 \% \text { sunny day } \\
\text { MAPE: } 54.44 \% \text { rainy day }\end{array}$ \\
\hline $\begin{array}{c}\text { [43] } \\
\text { Shi et al. }\end{array}$ & 2012 & SVM & $\begin{array}{l}\text { 1-day ahead } \\
15 \mathrm{~min}\end{array}$ & $\begin{array}{l}\text { Historical powers and weather } \\
\text { forecasts }\end{array}$ & 1 point & $\begin{array}{c}\text { China } \\
20 \mathrm{kWp}\end{array}$ & $\mathrm{MRE}=8.64 \%$ \\
\hline $\begin{array}{c}\text { [44] } \\
\text { Fernandez-Jimenez }\end{array}$ & 2012 & ANN & Up to $39 \mathrm{~h}$ ahead & $\begin{array}{l}\text { Historical powers and weather } \\
\text { forecasts }\end{array}$ & 3 points & $\begin{array}{l}\text { La Rioja, Spain } \\
36 \mathrm{kWp}\end{array}$ & MAPE $=0.85 \%$ \\
\hline $\begin{array}{c}{[45]} \\
\text { Izgi et al. }\end{array}$ & 2012 & ANN & $\begin{array}{l}5 \mathrm{~min}-40 \mathrm{~min} \\
1 \mathrm{~min}\end{array}$ & Historical powers & 1 point & $\begin{array}{l}\text { Istanbul, Turkey } \\
750 \mathrm{Wp}\end{array}$ & $\mathrm{RMSE}=65 \mathrm{~W}$ \\
\hline $\begin{array}{c}{[46]} \\
\text { Fonseca et al. }\end{array}$ & 2012 & SVR & $1 \mathrm{~h}$ ahead & $\begin{array}{c}\text { Forecasted parameters: } \\
\text { cloudiness and extraterrestrial } \\
\text { insolation }\end{array}$ & 1 point & $\begin{array}{l}\text { Kikakyushu, Japan } \\
1 \mathrm{MWp}\end{array}$ & $\mathrm{MAE}=0.058 \mathrm{MWh}$ \\
\hline $\begin{array}{c}{[47]} \\
\text { Zeng and Qiaop }\end{array}$ & 2013 & SVM & $1 \mathrm{~h}$ ahead & $\begin{array}{l}\text { Meteorological parameters: sky } \\
\text { cover, relative humidity, and } \\
\text { wind speed }\end{array}$ & 3 points & $\begin{array}{l}\text { Denver, Seattle and } \\
\text { Miami, U.S. }\end{array}$ & MAE: $35 \mathrm{~W}$ \\
\hline $\begin{array}{c}{[40]} \\
\text { Mellit at al. }\end{array}$ & 2014 & ANN & $\begin{array}{l}24 \mathrm{~h} \text { ahead } \\
5 \mathrm{~min}\end{array}$ & $\begin{array}{l}\text { Historical powers. On-site solar } \\
\text { irradiance and cell temperature }\end{array}$ & 1 point & $\begin{array}{l}\text { Puglia, Italy } \\
1 \mathrm{MWp}\end{array}$ & MAPE: $2 \%-12 \%$ \\
\hline $\begin{array}{l}{[48]} \\
\text { Giorgi et al. }\end{array}$ & 2014 & ANN & $\begin{array}{l}24 \mathrm{~h} \text { ahead } \\
\text { min }\end{array}$ & $\begin{array}{l}\text { On-site measurements of air } \\
\text { temperature, module } \\
\text { temperature, and in-plane solar } \\
\text { irradiance }\end{array}$ & 1 point & $\begin{array}{l}\text { Salerno, Italy } \\
960 \mathrm{kWp}\end{array}$ & $\mathrm{NMAE}=19.49 \%$ \\
\hline $\begin{array}{c}{[49]} \\
\text { Almonacid et al. }\end{array}$ & 2014 & ANN & $1 \mathrm{~h}$ ahead & $\begin{array}{l}\text { On-site measurements of solar } \\
\text { irradiance and air temperature }\end{array}$ & 1 point & $\begin{array}{l}\text { Jean, Spain } \\
44 \mathrm{kWp}\end{array}$ & $\mathrm{R} 2=0.98$ \\
\hline $\begin{array}{c}{[50]} \\
\text { Liu et al. }\end{array}$ & 2015 & ANN & 1 day ahead & $\begin{array}{c}\text { Historical powers, } \\
\text { temperatures, aerosol indexes, } \\
\text { wind speeds, and humidities }\end{array}$ & Regional forecast & $\begin{array}{l}\text { Minqin, Gansu } \\
10 \mathrm{MWp}\end{array}$ & MAPE $=7.65 \%$ \\
\hline $\begin{array}{c}{[51]} \\
\text { Gigoni et al. }\end{array}$ & 2015 & ENS & $\begin{array}{c}1 \text { day ahead } \\
1 \mathrm{~h}\end{array}$ & Forecast of solar irradiance & Regional forecast & $\begin{array}{c}\text { Italy } \\
114 \mathrm{MWp}\end{array}$ & nMAE: $1.27-4.04$ \\
\hline $\begin{array}{c}\text { [52] } \\
\text { Zhang et al. }\end{array}$ & 2015 & k-NN & 1 day ahead & $\begin{array}{l}\text { On-site measurements: solar } \\
\text { irradiance, temperature, wind } \\
\text { speed, and relative humidity }\end{array}$ & 3 points & $\begin{array}{l}\text { SanDiego, Braedstrup } \\
\text { and Catania, Italy } \\
49.2 \mathrm{kWp}, 5.21 \mathrm{kWp}, \\
\text { and } 15 \mathrm{kWp}\end{array}$ & nMAE: $7.4,6.38$ and 7.74 \\
\hline $\begin{array}{c}\quad[53] \\
\text { Ehsan et al. }\end{array}$ & 2016 & ANN & $\begin{array}{l}1 \text { day ahead } \\
15 \mathrm{~s}\end{array}$ & $\begin{array}{l}\text { On-site measurements: } \\
\text { Solar irradiance, air } \\
\text { temperature, wind speed, and } \\
\text { relative humidity }\end{array}$ & 1 point & $\begin{array}{l}\text { Tamil Nadu, India } \\
20 \mathrm{kWp}\end{array}$ & MAPE: $1.92 \%-11.28 \%$ \\
\hline
\end{tabular}


Table 2. Cont.

\begin{tabular}{|c|c|c|c|c|c|c|c|}
\hline Ref and Authors. & Year & Method & $\begin{array}{l}\text { Time Horizon and } \\
\text { Resolution }\end{array}$ & Parameters Used & $\begin{array}{l}\text { Point or Regional } \\
\text { Forecast }\end{array}$ & $\begin{array}{l}\text { Region and PV } \\
\text { Nominal Power }\end{array}$ & Accuracy \\
\hline $\begin{array}{c}{[54]} \\
\text { Baharin et al. }\end{array}$ & 2016 & SVR & $\begin{array}{l}12 \mathrm{~h} \text { ahead } \\
\text { min }\end{array}$ & $\begin{array}{l}\text { On site measurements: solar } \\
\text { irradiance and module } \\
\text { temperature }\end{array}$ & 1 point & $\begin{array}{l}\text { Melaka, Malaysia } \\
6 \mathrm{kWp}\end{array}$ & RMSE: $4.29 \%-6.85 \%$ \\
\hline $\begin{array}{c}{[55]} \\
\text { Pierro et al. }\end{array}$ & 2016 & MME & 1 day ahead & NWP models & 1 point & $\begin{array}{l}\text { Bolzano, Italy, } \\
662 \mathrm{kWp}\end{array}$ & RMSE $=10.5 \%$ \\
\hline $\begin{array}{c}{[56]} \\
\text { Li et al. }\end{array}$ & 2016 & ML-H & $\begin{array}{l}15 \mathrm{~min}, 1 \mathrm{~h} \text { and } 24 \mathrm{~h} \\
\text { ahead }\end{array}$ & Historical power and NWP & 1.point & $\begin{array}{l}\text { Florida, U.S. } \\
6 \mathrm{MWp}\end{array}$ & $\mathrm{MAE}=128.77 \mathrm{kWh}$ \\
\hline $\begin{array}{c}{[57]} \\
\text { Paulescu et al. }\end{array}$ & 2017 & FL & $\begin{array}{c}72 \mathrm{~h} \text { ahead } \\
1 \mathrm{~h}\end{array}$ & $\begin{array}{l}\text { Forecasted solar irradiance and } \\
\text { estimated solar cells }\end{array}$ & 2 points & $\begin{array}{l}\text { Catania, Italy } \\
5.21 \mathrm{kWp}\end{array}$ & MAE: 0.56 and $0.64 \mathrm{~kW}$ \\
\hline $\begin{array}{c}{[58]} \\
\text { Liu et al. }\end{array}$ & 2017 & FL & $1 \mathrm{~h}$ ahead & $\begin{array}{l}\text { Historical powers, air } \\
\text { temperature, humidity, and } \\
\text { insolation }\end{array}$ & 1 point & $\begin{array}{l}\text { Queensland, Australia. } \\
\qquad 33 \mathrm{kWp}\end{array}$ & $\mathrm{MAE}=9.77 \%$ \\
\hline $\begin{array}{c}{[59]} \\
\text { Das et al. }\end{array}$ & 2017 & SVM & $\begin{array}{l}24 \mathrm{~h} \text { ahead } \\
1 \mathrm{~h}\end{array}$ & $\begin{array}{l}\text { Historical powers and } \\
\text { meteorological data }\end{array}$ & 3 points & $\begin{array}{c}\text { Kuala Lumpur, } \\
\text { Malaysia } \\
1.875 \mathrm{MWp} \\
2 \mathrm{MWp} \\
2.7 \mathrm{MWp}\end{array}$ & Average $\mathrm{MAE}=34.57 \%$ \\
\hline $\begin{array}{c}{[60]} \\
\text { Leva et al. }\end{array}$ & 2017 & ANN & $\begin{array}{l}1 \text { day ahead } \\
1 \mathrm{~h}\end{array}$ & $\begin{array}{l}\text { Weather data and historical } \\
\text { measurements }\end{array}$ & 1 point & $\begin{array}{l}\text { Milano, Italy } \\
264 \mathrm{kWp}\end{array}$ & $\mathrm{MAE}<15 \%$ \\
\hline $\begin{array}{c}{[61]} \\
\text { Pierro et al. }\end{array}$ & 2017 & ANN & $\begin{array}{l}\text { Up to } 48 \mathrm{~h} \\
1 \mathrm{~h}\end{array}$ & Satellite data and NWP models & Regional & $\begin{array}{l}\text { Italy, } \\
68.2 \mathrm{MW}\end{array}$ & $\begin{array}{c}\text { RMSE: } 5 \%-7 \% \text { for } 1-4 \mathrm{~h} \\
\text { RMSE: } 7 \%-7.5 \% \text { for } 1-2 \\
\text { days }\end{array}$ \\
\hline $\begin{array}{c}{[62]} \\
\text { Liu et al. }\end{array}$ & 2018 & $\begin{array}{l}\text { SVM and } \\
\text { ANN }\end{array}$ & $1 \mathrm{~h}$ ahead & $\begin{array}{l}\text { On-site measurements: } \\
\text { temperature, relative humidity, } \\
\text { and aerosol }\end{array}$ & 1 point & $\begin{array}{l}\text { Beijing, China } \\
1.2 \mathrm{kWp}\end{array}$ & $\mathrm{MRE}=11.61 \%$ \\
\hline $\begin{array}{c}{[63]} \\
\text { Al-Dahidi }\end{array}$ & 2018 & ELM-ANN & $24 \mathrm{~h}$ ahead & $\begin{array}{l}\text { On-site measurements: solar } \\
\text { irradiance and air temperature }\end{array}$ & 1 point & $\begin{array}{l}\text { Amman, Jordan } \\
264 \mathrm{kWp}\end{array}$ & $\mathrm{MAE}=1.08 \%$ \\
\hline $\begin{array}{c}{[64]} \\
\text { Yao et al. }\end{array}$ & 2019 & ESN & $1 \mathrm{~h}$ ahead & Historical output powers & 1 point & China & MAPE $=-0.00195 \%$ \\
\hline $\begin{array}{c}{[65]} \\
\text { Han et al. }\end{array}$ & 2019 & ELM & Few hours interval & $\begin{array}{l}\text { Historical data powers and } \\
\text { NWP meteorological data: solar } \\
\text { irradiance, air temperature, } \\
\text { wind speed, and relative } \\
\text { humidity. }\end{array}$ & 1 point & $\begin{array}{l}\text { China } \\
250 \mathrm{kWp}\end{array}$ & $\mathrm{MAE}=2.13 \%$ \\
\hline
\end{tabular}


In [47] the authors described a SVM-based model for the short-term forecasting of the power produced by three PV plants installed in three different regions of the U.S. The data used to develop the model was provided by the National Solar Radiation Database (NSRDB). This study showed that normalizing the solar irradiation values with respect to the transmissivity gives better results than using a standard sigmoid function-based normalization. The proposed technique was compared with a RBF-NN-based model showing a better accuracy. The authors suggested that the addition of the information regarding the sky cover can improve the prediction accuracy.

A simple but accurate approach for short-term forecasting regarding a large-scale PV plant is presented in [40]. The model was calibrated using the on-site measured powers, cell-temperatures, and solar radiations regarding a one MWp PV plant installed in the southern part of Italy. This work showed that adding more hidden layers does not lead to better accuracies, but increases the convergence time. The authors pointed out that the proposed models do not require any additional parameter and that they can be easily implemented.

A multiple regression analysis has been performed in order to determine the most significant input parameters (among module and air temperature, in-plane solar irradiation, and produced power) to be used in an extreme machine learning NN used to forecast the power produced by a $960 \mathrm{kWp}$ PV system located at Salerno, Italy [48]. The model was evaluated for a forecasting horizon in the range [1-24 h].

In [49] the authors developed a dynamic NN to forecast one hour-ahead the power produced by a $44 \mathrm{k} \mathrm{Wp} \mathrm{PV} \mathrm{plant} \mathrm{installed} \mathrm{at} \mathrm{the} \mathrm{Jean} \mathrm{University} \mathrm{in} \mathrm{Spain.} \mathrm{In} \mathrm{this} \mathrm{case,} \mathrm{an} \mathrm{ANN} \mathrm{was} \mathrm{used} \mathrm{to}$ predict the solar irradiance and the air temperature that are then used as an input of a second ANN forecasting the produced power. In [50] the authors developed a method using an ANN for a one day-ahead PV power forecasting. The aerosol index has been used as an input as the solar irradiance is a parameter that is not always measured and/or available. The MAE was $7.65 \%$, and the authors concluded that in the future data from remote sensors could represent a valuable input in the field of PV power forecasting. Different methods have been investigated in [51] including a grey-box model, NNs, k-nearest neighbors (kNNs), quantile random forest (QRF), SVM, and ensemble of methods (ENS). The application of these techniques gave similar performances showing a MAE close to 5\%. However, ENS was the best forecaster considering variable weather condition. The authors concluded that the investigated methods proved the feasibility to produce good results even without using the temperature as an input parameter.

In [52] the authors used a k-NN-based method for forecasting the power produced by small-scale PV plants installed in three different regions: SanDiego, Braedstrup and Catania. They concluded that simple techniques such as $k$-NNs can produce relatively accurate forecasts (the nMAE was in fact $0.96 \%$ ).

The well-known MLP-ANN was used to estimate one day-ahead the power profile of a small-scale grid-connected 20-kWp PV plant installed at Tamil Nadu, India [53]. The MAE was in the range $[1.92 \%-11.28 \%]$. In this case, a number of learning algorithms has been investigated, while the Levenberg-Marquardt and Delta-Bar-Delta have shown the best performance.

In [54] the authors used a SVR-based method applied to a small-scale PV plant located in Melaka, Malaysia. The use of different input has been investigated including the tilted and horizontal global irradiance, and the module temperature. The results showed that the model performs well in the tropical climate with a RMSE that was in the range [4.29\%-6.85\%].

A large dataset both from NPW and measurements from the field has been used to train different multi-model ensembles (MME) including SVM, ANN, and statistic models [55]. The investigated PV plant is located in Bolzano (Italy), and its capacity is $662 \mathrm{kWp}$. This work showed that the same algorithms differ in performance when using as input NWP data with comparable accuracy.

A hierarchical-based approach with different time horizons (15 min, $1 \mathrm{~h}$, and $24 \mathrm{~h}$ ) was used in [56]. In this case, many different parameters have been used as an input including the plant output 
power, a number of environmental variables coming from NWP, and the geometry of the system. The conclusion was that this method performs better than others based on ANNs and SVR.

In [57] the author developed an advanced fuzzy-logic method for forecasting the output power of two PV plants installed in Milano and Catania, Italy. The model was used to forecast the output power with a time horizon in the range $[1 \mathrm{~h}-72 \mathrm{~h}]$. The MAE was $0.56 \mathrm{~kW}$ for the PV plant installed in Catania and $0.64 \mathrm{~kW}$ for the one in Milano. This work showed that all investigated models including generalized adaptive, physical inspired, semi-statistical methods perform better in summer than in winter, while have similar performance in summer and autumn.

The T-S fuzzy-based approach proposed in [58] uses as an input a number of meteorological parameters. The model was compared with other methods such as SVM, MLP-ANN, RNN, and other empirical models. The results showed that the proposed model outperforms all others with a quite low $\mathrm{MAE}=9.77 \%$ in summer, but a high $\mathrm{MAE}=30 \%$ in spring.

In [59] the authors designed a SVM-based model for a one day-ahead forecasting. The model accepts as an input the historical powers and some meteorological data. The method was tested to forecast the PV power generation for different conditions corresponding to clear-sky, cloudy and rainy days, and for three locations in Malaysia. The results in terms of MAE $=34.57 \%$ has shown the good forecast ability of the proposed model.

In [60] a MLP-based forecaster was trained using weather forecasts and historical data. The model performed better during sunny than partially cloudy days. The normalized MAE was lower than $15 \%$ for all the investigated cases.

A new upscaling method was developed for estimating the power produced by a PV plant installed in Italy [61]. The method uses data from satellite and NWP to estimate the solar generation on a regional scale. The method was applied to the power generation of 1985 small-scale PV plants installed in the South Tyrol Region, Italy (the total covered area was $800 \mathrm{~km}^{2}$ ). The RMSE was in the range $[5 \%-7 \%]$ for a time horizon of $4 \mathrm{~h}$, and in the range $[7 \%-7.5 \%]$ for the 1-day estimation.

SVM and a MLP have been used to for the ultra-short-term forecasting of a small-scale PV plant installed in Beijing, China [62]. According to the authors, the designed model is particularly efficient and especially designed for particular environmental conditions with fog and haze. The input of these forecasters comprises the on-site measurements of air temperature, relative humidity, and aerosol indexes.

In [63] an ELM algorithm has been developed in order to train a MLP network that forecasts 24-h ahead the power produced by a PV plant installed at Amman, Jordan. The ELM outperforms the classical back propagation (BP) algorithm in terms of accuracy. The technique showed the smallest MAE $=1.08 \%$ in June, while the biggest MAE $=18.83 \%$ and corresponded to February and March.

A multiple reservoirs echo state network (MR-ESN) based model has been proposed for in [64]. The quasi Newton algorithm has been used to optimize the reservoir parameters. The results showed a MAPE very close to zero $(0.00195 \%)$ and, with reference to one-hour forecast horizon, the model performed better than other techniques such as SVM, back-propagation neural networks (BPNNs), support vector regression (SVR-ANN), and wavelet transform (WT).

A multi-model ELM-based forecaster was proposed in [65] for the forecasting of the power produced by $250 \mathrm{kWp}$ PV plant installed in Beijing, China. With reference to the accuracy of the multi-model, the MAE was $2.13 \%$ in spring and $1.7 \%$ in summer, while for an annual single model the MAE was $2.43 \%$ in spring and $1.81 \%$ in summer. The designed multi-model takes into account the fluctuation of the power output in order to improve the accuracy. 


\subsection{Application of Deep Learning in PV Power Forecasting}

Table 3 reports a summary of different deep learning-based techniques published during the period 2011-2019 for forecasting the power produced by PV plants.

In [66] five LSTM-based neural networks have been designed to forecast the hourly PV output power. The proposed model, that does not use any meteorological data and is based on historical powers, offered a reduction in the forecasting error compared with other methods.

A six-layer feedforward deep neural network for one day-ahead PV power forecasting of a grid connected photovoltaic system installed in Seoul, Korea has been presented in [67]. The method, that does not require the use of any on-site sensors, has shown better performance than other models using local measurements. Nevertheless, the achieved errors during summer and cloudy weather were not satisfactory.

In [68], the authors proposed a comparative study between different deep neural networks-based one-day ahead forecasters. The study includes conventional neural networks (CNNs), LSTM, and a hybrid model that combine CNNs and LSTMs. It has been shown that the accuracy of the three models mainly depends on the size of the available database. Generally, the experimental results show that the deep learning network has a good effect on the prediction of photovoltaic power generation and the stability and robustness of the model are high.

A recurrent LSTM-based method has been designed for the hourly short-term forecasting of the power produced by a PV plant installed in Gumi, South of Korea [69]. The model accepts as an input the solar irradiance, the ambient temperature, and the cloudiness index. The results showed the best performance compared with other approaches based on DNN, ANN, auto regressive integrated moving average (ARIMA), and seasonal-ARIMA. LSTMs perform particularly well, especially in the case of instable power output. 
Table 3. DL-based methods for the forecast of PV power-period 2017-2019.

\begin{tabular}{|c|c|c|c|c|c|c|c|}
\hline Ref and Authors & Year & Method & Time Horizon & Parameters Used & $\begin{array}{l}\text { Point or Regional } \\
\text { Forecast }\end{array}$ & $\begin{array}{l}\text { Region and PV } \\
\text { Nominal Power }\end{array}$ & Accuracy \\
\hline $\begin{array}{c}{[66]} \\
\text { Mahmou et al. }\end{array}$ & 2017 & $\begin{array}{l}\text { Deep LSTM } \\
\text { network }\end{array}$ & $1 \mathrm{~h}$ ahead & Historical powers & 1 point & Aswan, Egypt & $\mathrm{RMSE}=82.15$ \\
\hline $\begin{array}{c}{[67]} \\
\text { Son et al. }\end{array}$ & 2018 & DNN & $24 \mathrm{~h}$ ahead & Weather forecast & 1 point & $\begin{array}{l}\text { Seoul, Korea } \\
2.448 \mathrm{kWp}\end{array}$ & $\mathrm{MAE}=2.9 \%$ \\
\hline $\begin{array}{c}{[68]} \\
\text { Wang et al. }\end{array}$ & 2019 & $\begin{array}{l}\text { CNN, LSTM and } \\
\text { CNN+LSTM }\end{array}$ & 1 day ahead & $\begin{array}{c}\text { On-site } \\
\text { measurements:active power, } \\
\text { current, wind speed, } \\
\text { irradiance, humidity, and } \\
\text { air temperature }\end{array}$ & 1 point & $\begin{array}{l}\text { Trina, China, } \\
23.4 \mathrm{kWp}\end{array}$ & $\begin{array}{l}\text { RMSE }=0.343 \%, \\
\text { MAE }=0.126 \%, \\
\text { MAPE }=0.022 \%\end{array}$ \\
\hline $\begin{array}{c}{[69]} \\
\text { Lee et al. }\end{array}$ & 2019 & RNN-LSTM DNN & $1 \mathrm{~h}$ ahead & $\begin{array}{l}\text { On-site measurement and } \\
\text { cloudiness data }\end{array}$ & 1 point & $\begin{array}{c}\text { Gumi, South of } \\
\text { Korea } \\
40 \mathrm{kWp}\end{array}$ & $\mathrm{MAE}=0.23 \%$ \\
\hline
\end{tabular}




\subsection{Hybrid Methods-Based Forecasting}

Table 4 summarizes the main research regarding hybrid methods carried out during the period 2012-2019.

A number of forecasting techniques using no exogenous inputs for the prediction of the power produced by a $1 \mathrm{MWp}$ power plant have been presented in [70]. The hybrid genetic algorithm ANN-based outperforms the other investigated techniques such as kNN, ANN, and ARIMA-based.

In [25], the authors introduced a hybrid model for the short-term power forecasting of a small-scale PV system installed on the rooftop of the municipality of Trieste, Italy. The model combines a SVM approach with a seasonal auto-regressive integrated moving average method (SARIMA). The result was that the designed hybrid model performs better than the SVM and SARIMA model working alone.

In order to improve the speed of convergence and the accuracy of the prediction, a new hybrid genetical swarm optimization (GSO)/error back propagation (EBP)-based technique was developed in [71]. The method was tested for the 24-h power forecasting regarding a small-scale plant installed at Milano, Italy. The result was an improvement of performances with respect to the standard EBP alone.

A hybrid methodology combining SVM, self-organization map (SOM), and fuzzy logic (FL) for a one day-ahead forecasting is proposed in [72]. In this work, SOM was used to classify the type of weather, the SVM for the training phase, and the FL in order to select the most accurate training model coming from the SVM. The data used to develop the method was from the Taiwan Central Weather Bureau (TCWB). This hybrid forecaster outperformed both the traditional SVR and ANN-based models.

In [73], the authors presented an optimized GANN-based method for intra-hourly reforecasting the power produced by a large-scale plant installed in San Diego, U.S. The results showed the effectiveness of the optimized reforecasting method in reducing the errors produced by a number of different forecast methodologies including deterministic models, k-NN, and ARMA.

In [74] the authors developed a method for forecasting hour-ahead the power produced by a 5 kWp PV plant installed in Taiwan. The hybrid method consists of a fuzzy k-means algorithm for the classification of the historical daily PV power, five RBFN to forecast the produced power, and a fuzzy logic controller to select the appropriate RBFN for the considered conditions. In this case, the input data were the actual solar irradiation, precipitation level, and the temperature forecast. 
Table 4. Hybrid methods for the forecast of PV power-period 2012-2019.

\begin{tabular}{|c|c|c|c|c|c|c|c|}
\hline Ref and Authors & Year & Method & Time Horizon & Parameters Used & $\begin{array}{l}\text { Point Regional } \\
\text { Forecast }\end{array}$ & $\begin{array}{l}\text { Region and PV } \\
\text { Nominal Power }\end{array}$ & Accuracy \\
\hline $\begin{array}{c}{[70]} \\
\text { Pedro et al. }\end{array}$ & 2012 & ANN-GA & $1 \mathrm{~h}$ and $2 \mathrm{~h}$ ahead & $\begin{array}{l}\text { Historical measurement of the } \\
\text { output power }\end{array}$ & 1-point & $\begin{array}{c}\text { Central California, US } \\
1 \mathrm{MWp}\end{array}$ & $\begin{array}{l}1 \mathrm{~h}-\mathrm{MAE}=42.96 \mathrm{~kW} \\
2 \mathrm{~h}-\mathrm{MAE}=57.53 \mathrm{~kW}\end{array}$ \\
\hline $\begin{array}{c}{[25]} \\
\text { Bouzerdoum et al. }\end{array}$ & 2013 & SVM-ARIMA & $\begin{array}{l}1 \mathrm{~h} \text { ahead } \\
5 \mathrm{~min}\end{array}$ & $\begin{array}{c}\text { Historical measurement of } \\
\text { powers }\end{array}$ & 1-point & $\begin{array}{l}\text { Trieste, Italy } \\
20 \mathrm{kWp}\end{array}$ & $\mathrm{MPE}=2.73 \%$ \\
\hline $\begin{array}{c}{[71]} \\
\text { Ogliari et al. }\end{array}$ & 2013 & $\begin{array}{l}\text { MLP-GSO-Physical } \\
\text { model }\end{array}$ & Up to $24 \mathrm{~h}$ & $\begin{array}{l}\text { Weather forecasts and historical } \\
\text { powers }\end{array}$ & 1-point & $\begin{array}{l}\text { Milano, Italy, } \\
30 \mathrm{kWp}\end{array}$ & $\mathrm{MAE}=0.317 \mathrm{~kW}$ \\
\hline $\begin{array}{c}\text { [72] } \\
\text { Yan et al. }\end{array}$ & 2013 & SVM-FL-SOM-LVQ & $\begin{array}{c}\text { 1-day ahead } \\
\text { h }\end{array}$ & $\begin{array}{l}\text { Air temperature, probability of } \\
\text { precipitation, and solar irradiance }\end{array}$ & 1-point & $\begin{array}{l}\text { Taiwan } \\
5 \mathrm{kWp}\end{array}$ & $\mathrm{MRE}=[1.79-4.69]$ \\
\hline $\begin{array}{c}\text { [73] } \\
\text { Chu et al. }\end{array}$ & 2015 & $\begin{array}{l}\text { ANN-GA, kNN } \\
\text { ARMA }\end{array}$ & $\begin{array}{c}\text { Intra-hour } \\
\mathrm{s}\end{array}$ & $\begin{array}{c}\text { Historical powers and imaging } \\
\text { data }\end{array}$ & 1 point & $\begin{array}{l}\text { Sandiego, US } \\
48 \mathrm{MWp}\end{array}$ & $\mathrm{MAE}=20.7 \mathrm{kWp}$ \\
\hline $\begin{array}{c}{[24]} \\
\text { Dolara et al. }\end{array}$ & 2015 & PHANN & $\begin{array}{l}\text { Up to } 72 \mathrm{~h} \\
\mathrm{~h}\end{array}$ & $\begin{array}{c}\text { Weather forecast and onsite } \\
\text { measurements }\end{array}$ & 1-point & $\begin{array}{l}\text { Milano, Italy } \\
264 \mathrm{kWp}\end{array}$ & $\mathrm{NMAE}=[6.4 \%-12.5 \%]$ \\
\hline $\begin{array}{c}{[74]} \\
\text { Huang et al. }\end{array}$ & 2015 & $\begin{array}{l}\text { Fuzzy- K means, } \\
\text { RBFN }\end{array}$ & 1 day ahead & $\begin{array}{l}\text { Actual solar irradiance and } \\
\text { predicted maximum temperature } \\
\text { and precipitation }\end{array}$ & 1-point & $\begin{array}{l}\text { Taiwan, } \\
5 \mathrm{kWp}\end{array}$ & $\mathrm{MAE}=3.25 \%$ \\
\hline $\begin{array}{c}{[75]} \\
\text { Wang et al. }\end{array}$ & 2017 & $\begin{array}{c}\text { Hybrid } \\
\text { WT-CDNN-QR }\end{array}$ & $\begin{array}{l}15 \mathrm{~min}, 30 \mathrm{~min}, 1 \mathrm{~h} \\
\text { and } 2 \mathrm{~h} \text { ahead }\end{array}$ & $\begin{array}{c}\text { Historical measurement of the } \\
\text { output power }\end{array}$ & 2 points & $\begin{array}{c}\text { Belgium, China } \\
1.5 \mathrm{MW}\end{array}$ & $\mathrm{MAE}=[0.58 \%, 2.96 \%]$ \\
\hline $\begin{array}{c}{[76]} \\
\text { Dolara et al. }\end{array}$ & 2018 & PHANN & 1 day ahead & $\begin{array}{c}\text { Weather and historical } \\
\text { measurement }\end{array}$ & 1-point & $\begin{array}{l}\text { Milano, Italy } \\
245 \mathrm{kWp}\end{array}$ & NMAE $=5.1 \%$ \\
\hline $\begin{array}{c}{[77]} \\
\text { Behera et al. }\end{array}$ & 2018 & Hybrid PSO-ELM & $\begin{array}{c}15 \mathrm{~min}, 30 \mathrm{~min} \\
\text { ahead }\end{array}$ & $\begin{array}{l}\text { Historical data: solar irradiance } \\
\text { and air temperature }\end{array}$ & 1-point & $\begin{array}{c}\text { Bhubaneswar India. } \\
120 \mathrm{Wp} \\
\end{array}$ & $\begin{aligned} 15-\min \mathrm{MAE} & =0.029 \% \\
60-\min \mathrm{MAE} & =0.51 \%\end{aligned}$ \\
\hline $\begin{array}{c}{[78]} \\
\text { Cervone et al. }\end{array}$ & 2018 & $\begin{array}{c}\text { Hybrid } \\
\text { ANN+AnEn }\end{array}$ & $72 \mathrm{~h}$ ahead & $\begin{array}{l}\text { On-site measurements, weather, } \\
\text { and astronomical variables }\end{array}$ & 3 points forecast & $\begin{array}{c}\text { One in the north and } \\
\text { two in the south of Italy } \\
5.21 \mathrm{kWp} \\
4.99 \mathrm{kWp} \\
5.29 \mathrm{kWp}\end{array}$ & $\begin{array}{c}\mathrm{MAE}=-1.85 \% \\
0.38 \%-1.53 \%\end{array}$ \\
\hline $\begin{array}{c}79] \\
\text { Ogliari et al. }\end{array}$ & 2018 & PHANN & 1 day ahead & $\begin{array}{l}\text { Weather forecasts, day of the year, } \\
\text { and location }\end{array}$ & 1-point & $\begin{array}{l}\text { Milano, Italy } \\
285 \mathrm{Wp}\end{array}$ & $\mathrm{NMAE}=3.79 \%$ \\
\hline
\end{tabular}


Table 4. Cont

\begin{tabular}{|c|c|c|c|c|c|c|c|}
\hline Ref and Authors & Year & Method & Time Horizon & Parameters Used & $\begin{array}{l}\text { Point Regional } \\
\text { Forecast }\end{array}$ & $\begin{array}{l}\text { Region and PV } \\
\text { Nominal Power }\end{array}$ & Accuracy \\
\hline $\begin{array}{c}{[80]} \\
\text { Nespoli et al. }\end{array}$ & 2018 & PHANN & 1 day ahead & $\begin{array}{l}\text { Weather forecasts, day of the year, } \\
\text { and location }\end{array}$ & 1-point & $\begin{array}{l}\text { Milano, Italy } \\
285 \mathrm{Wp}\end{array}$ & $\mathrm{NMAE}=3.39 \%$ \\
\hline $\begin{array}{c}{[81]} \\
\text { Zang et al. }\end{array}$ & 2019 & $\begin{array}{c}\text { Hybrid } \\
\text { VMD-CNN-SVR }\end{array}$ & $\begin{array}{l}\text { Various hour time } \\
\text { scales }\end{array}$ & Historical power & 1-point & $\begin{array}{l}\text { Nanjing, China. } \\
100 \mathrm{kWp}\end{array}$ & $\mathrm{MAE}=1.54 \%$ \\
\hline $\begin{array}{c}\text { [82] } \\
\text { Eseye et al. }\end{array}$ & 2019 & $\begin{array}{c}\text { Hybrid } \\
\text { WT-PSO-SVM }\end{array}$ & 1 day ahead & $\begin{array}{l}\text { SCAD historical powers, } \\
\text { NWP meteorological }\end{array}$ & 1-point & $\begin{array}{l}\text { Beijing, China. } \\
480 \mathrm{kWp}\end{array}$ & NMAE $=0.4 \%$ \\
\hline $\begin{array}{c}{[83]} \\
\text { Van Deventer et al. }\end{array}$ & 2019 & Hybrid GA-SVM & $1 \mathrm{~h}$ ahead & $\begin{array}{l}\text { On-site measurements of PV } \\
\text { power, solar irradiance, and air } \\
\text { temperature }\end{array}$ & 1 point & $\begin{array}{l}\text { Deakin, Malaysia } \\
\quad 3 \mathrm{kWp}\end{array}$ & $\mathrm{MAPE}=98.76 \mathrm{~W}$ \\
\hline $\begin{array}{c}{[84]} \\
\text { Gao et al. }\end{array}$ & 2019 & LSTM-NN & 2 days ahead & $\begin{array}{l}\text { On-site weather data and } \\
\text { historical powers }\end{array}$ & 1 point & $\begin{array}{l}\text { Beijing, China } \\
10 \text { MWp }\end{array}$ & $\begin{array}{c}\text { MAD }=1.41 \% \text { and } \\
3.97 \%\end{array}$ \\
\hline $\begin{array}{c}{[85]} \\
\text { Ospina et al. }\end{array}$ & 2019 & SWT-LSTM-DNN & $\begin{array}{l}24 \mathrm{~h} \text { ahead } \\
30 \text { min }\end{array}$ & $\begin{array}{l}\text { Historical PV powers and } \\
\text { temperature }\end{array}$ & 1 point & $\begin{array}{l}\text { Florida, USA, } \\
12.6 \mathrm{MW}\end{array}$ & \\
\hline
\end{tabular}


A model based on a hybrid deterministic-probabilistic method for PV power forecasting has been described in [75]. The technique combines WT to decompose the signal, deep convolutional neural network (DCNN) to extract the nonlinear features and invariant structures in the decomposed signal, and quantile regression $(\mathrm{QR})$ to statistically evaluate the forecasted power. The model was evaluated at two different locations and for different time horizons (14 $\mathrm{min}, 30 \mathrm{~min}, 1 \mathrm{~h}$, and $2 \mathrm{~h}$ ). The model was trained only using historical output powers, and compared with other approaches based on SVM, BPNN, and SVM-WT.

The effect of different training approaches for the day-ahead forecasting of the power produced by a $245 \mathrm{Wp}$ PV plant installed in Milano, Italy, was analyzed and discussed in [76]. In particular, the influence of the dataset size and the way in which data were employed in the training step was found to be of paramount importance.

To enhance the accuracy in the forecasting, an ELM has been optimized using different adaptive PSO algorithms (APSO-ELM) in [77]. The result was a better performance in the short-term solar forecasting with respect to other techniques.

A method combining a NN-based approach with an analog ensemble (AnEn) was proposed in [78] for the short-term forecasting of the power produced by a number of PV arrays. The method was tested for three different PV plants installed in Italy with a time horizon of $72 \mathrm{~h}$, and according to the authors the proposed solution is particularly suitable for massive scale computation.

It has previously demonstrated in [24] that a dual layer ANN hybridized with the Clear sky solar radiation algorithm, namely the physical hybrid neural network model (PHANN), improved the day-ahead forecast accuracy compared to the pure ANN. In addition, it was demonstrated that the PHANN method always outperformed the day-ahead power forecast obtained with the physical five parameter equivalent model of a PV module, located in Milan, Italy [27]. Besides, a mixed forecasting technique is described in [79]. Here, the authors improved the accuracy of some weather forecasts using a physical neural network model (PHANN) and optimizing the five-parameter model with a social network optimization (SNO). The method clearly improved the forecast accuracy in the prediction of the power produced by a PV plant installed at Milano, Italy. The same hybrid method scored better results with different time horizon forecasts [80].

In [81], a hybrid technique using a variation mode decomposition (VMD) method together with a CNN was developed for the short-term power forecasting of a $100 \mathrm{kWp}$ plant installed at Nanjing, China. The VDM was used to decompose the PV power time series into different frequencies and into 2D data, while the power was estimated by a SVR model. It has been shown that the method presents a higher prediction accuracy with respect to other 1D VMD-based forecasting methods.

A hybrid WT-PSO-SVM- based method for the short-term prediction of the power produced by a PV system installed in China was presented in [82]. In this case, the input data were the PV system powers and the meteorological parameters from NWP. The results showed the better performance of the designed technique with respect to others based on HGNN, HPNN, BPNN, and SVM.

In [83] a hybrid SVM-GA model has been devised and validated for the short-term PV power forecasting. The SVM technique was used to classify the weather, while the GA to optimize for the optimization of the model. The hybrid GA-SVM model outperformed the SVM in point of view accuracy forecasting.

LSTM networks have been used for one day ahead power forecasting regarding a large-scale PV plant in China [84]. The method classifies the weather into ideal and non-ideal conditions, and a discrete grey model has been developed for the power prediction.

A hybrid model based on stationarity wavelet networks (SWN), LSTM, and DNN for the short-term forecasting of the power produced by a small-scale and a large-scale PV plant has been presented in [85]. The model used the temperatures estimated by the SWM, while the LSTM was used to extract the historical powers, and the DNN to predict the powers. 


\section{Concluding Remarks and Future Trends}

In this paper, an extensive review of the recent applications of AI techniques-including ML, DL, and hybrid methods-to PV output power forecasting, is presented. The key conclusions and future directions that can be inferred are:

While the development of forecasters based on ML in general has been investigated rather intensively, the application of DL for PV power prediction has been rather limited so far.

$\checkmark$ Most researchers have focused on forecasting at single locations, while little work has been done on regional models; no accurate general regional model has been proposed to date.

$\checkmark$ The most investigated time horizon is in the short-term regime (up to few days) — which is also the most requested and used. ML-based forecasters are well suited for this case, particularly when combined with appropriate algorithms—such as ANN-optimized GA or PSO.

$\checkmark$ Very-short-term forecasting and long-term forecasting have been scarcely investigated.

$\checkmark$ Most AI-based models perform well for sunny days, while for cloudy days the forecasting accuracy decreases significantly.

$\checkmark$ The accuracy of AI-models decreases for longer time horizons, especially beyond $72 \mathrm{~h}$.

$\checkmark$ ML methods based on historical power output, and the use of meteorological parameters (such as air temperature, solar irradiance, relative humidity, wind speed, cloud cover), combined with an optimal learning algorithm and weather classification can improve forecasting accuracy.

$\checkmark$ One-step ahead forecasting performs best, and has been extensively investigated. Conversely, multistep-ahead predictions remain a challenging task.

$\checkmark$ Hybrid models (e.g., the combination of physical models with ML methods such as ANN) improve forecasting accuracy.

Generally, in order to increase the accuracy of the forecasters based on AI techniques, the following points should be considered: (1) large datasets with good-quality data are preferable; (2) pretreatment and analysis of the database to identify outliers and missing data is required; (3) exogenous inputs should be taken into account, such as for example cloud variation; (4) combination with other physical models.

Long-term PV power forecasting could be achieved by using NWP models and DL including LSTM and CNN, as the latter (as well as RNN) have some useful characteristics, such as the ability of estimating the temporal dependencies of the investigated data, and the ability of performing a more general feature extraction. With the increasing amount of data (on-site measurements based on SCADA, satellite image data, NWP models), DL will become increasingly interesting for PV power prediction, in particular for designing accurate regional forecasters. An extensive investigation is still needed on DL-based forecasting methods. DL has been gaining popularity in particular for time series forecasting, due to the availability of increasingly large datasets and open sources codes (e.g., Python, TensorFlow, Keras, etc.). ML based models, on the other hand, have shown their capability for PV power forecasting as well as DL based models, while the accuracy depends mainly on the data quality, their amount and the learning algorithms. However, DL based models are more suitable in the case of large database, unlike ML based models.

The improvement of model accuracy for cloudy days is still only marginally investigated. Forecasting approaches able to estimate and classify cloud cover and to use these parameters for DL models is expected to lead to sizeable accuracy improvement.

The combination of physical models with DL-based methods (e.g., DCNN) has been scarcely investigated. However, such an approach could significantly improve forecasting accuracy.

Author Contributions: Conceptualization, A.M.; methodology, A.M. and A.M.P.; validation, A.M.P. and E.O.; formal analysis, S.L.; investigation, A.M. and S.L.; resources, A.M.; data curation, A.M.P. and E.O.; writing-original draft preparation, A.M.; writing—review and editing, A.M.P., E.O., and V.L.; visualization, A.M. and A.M.P.; 
supervision, S.L.; project administration, S.L. and A.M.P. All authors have read and agreed to the published version of the manuscript.

Funding: This research received no external funding.

Acknowledgments: A. Mellit would like to thank the International Centre for Theoretical Physics (ICTP), Trieste (Italy) for providing the materials and the computer facilities used to develop some parts of the work presented in the paper.

Conflicts of Interest: The authors declare no conflict of interest.

\section{References}

1. IEA. Sunspot of Global Markets. “Renewables 2018. Solar Energy”. Available online: https://www.iea.org/ topics/renewables/solar/ (accessed on 20 December 2019).

2. Sperati, S.; Alessandrini, S.; Pinson, P.; Kariniotakis, G. The Weather Intelligence for Renewable Energies benchmarking exercise on short-term forecasting of wind and solar power generation. Energies 2015, 8, 9594-9619. [CrossRef]

3. Pelland, S.; Remund, J.; Kleissl, J.; Oozeki, T.; De Brabandere, K. Photovoltaic and Solar Forecasting: State of the Art; IEA PVPS Task 14, Subtask 3.1. Report Iea-PVPS T14-01: 2013; International Energy Agency: Paris, France, 2013.

4. Antonanzas, J.; Osorio, N.; Escobar, R.; Urraca, R.; Martinez-de-Pison, F.J.; Antonanzas-Torres, F. Review of photovoltaic power forecasting. Sol. Energy 2016, 136, 78-111. [CrossRef]

5. Raza, M.Q.; Nadarajah, M.; Ekanayake, C. On recent advances in PV output power forecast. Sol. Energy 2016, 136, 125-144. [CrossRef]

6. Wan, C.; Zhao, J.; Song, Y.; Xu, Z.; Lin, J.; Hu, Z. Photovoltaic and solar power forecasting for smart grid energy management. IEEE CSEE J. Power Energy Syst. 2015, 1, 38-46. [CrossRef]

7. Taieb, S.B.; Bontempi, G.; Atiya, A.F.; Sorjamaa, A. A review and comparison of strategies for multi-step ahead time series forecasting based on the NN5 forecasting competition. Expert Syst. Appl. 2012, 39, 7067-7083. [CrossRef]

8. Nespoli, A.; Ogliari, E.; Leva, S.; Massi Pavan, A.; Mellit, A.; Lughi, V.; Dolara, A. Day-ahead photovoltaic forecasting: A comparison of the most effective techniques. Energies 2019, 12, 1621. [CrossRef]

9. Wolff, B.; Kühnert, J.; Lorenz, E.; Kramer, O.; Heinemann, D. Comparing support vector regression for PV power forecasting to a physical modeling approach using measurement, numerical weather prediction, and cloud motion data. Sol. Energy 2016, 135, 197-208. [CrossRef]

10. Dolara, A.; Leva, S.; Manzolini, G. Comparison of different physical models for PV power output prediction. Sol. Energy 2015, 119, 83-99. [CrossRef]

11. Larson, D.P.; Nonnenmacher, L.; Coimbra, C.F. Day-ahead forecasting of solar power output from photovoltaic plants in the American Southwest. Renew. Energy 2016, 91, 11-20. [CrossRef]

12. Zhang, X.; Li, Y.; Lu, S.; Hamann, H.F.; Hodge, B.M.; Lehman, B. A solar time based analog ensemble method for regional solar power forecasting. IEEE Trans. Sustain. Energy 2018, 10, 268-279. [CrossRef]

13. Jang, H.S.; Bae, K.Y.; Park, H.S.; Sung, D.K. Solar power prediction based on satellite images and support vector machine. IEEE Trans. Sustain. Energy 2016, 7, 1255-1263. [CrossRef]

14. Pelland, S.; Galanis, G.; Kallos, G. Solar and photovoltaic forecasting through post-processing of the Global Environmental Multiscale numerical weather prediction model. Prog. Photovolt. Res. Appl. 2013, 21, $284-296$. [CrossRef]

15. Tuohy, A.; Zack, J.; Haupt, S.E.; Sharp, J.; Ahlstrom, M.; Dise, S.; Black, J. Solar forecasting: Methods, challenges, and performance. IEEE Power Energy Mag. 2015, 13, 50-59. [CrossRef]

16. Wang, G.; Su, Y.; Shu, L. One-day-ahead daily power forecasting of photovoltaic systems based on partial functional linear regression models. Renew. Energy 2016, 96, 469-478. [CrossRef]

17. Nobre, A.M.; Severiano, C.A., Jr.; Karthik, S.; Kubis, M.; Zhao, L.; Martins, F.R.; Reindl, T. PV power conversion and short-term forecasting in a tropical, densely-built environment in Singapore. Renew. Energy 2016, 94, 496-509. [CrossRef]

18. Yang, D.; Dong, Z. Operational photovoltaics power forecasting using seasonal time series ensemble. Sol. Energy 2018, 166, 529-541. [CrossRef] 
19. Agoua, X.G.; Girard, R.; Kariniotakis, G. Probabilistic Models for Spatio-Temporal Photovoltaic Power Forecasting. IEEE Trans. Sustain. Energy 2018, 10, 780-789. [CrossRef]

20. Bracale, A.; Carpinelli, G.; De Falco, P. A probabilistic competitive ensemble method for short-term photovoltaic power forecasting. IEEE Trans. Sustain. Energy 2016, 8, 551-560. [CrossRef]

21. Sanjari, M.J.; Gooi, H.B. Probabilistic forecast of PV power generation based on higher order Markov chain. IEEE Trans. Power Syst. 2016, 32, 2942-2952. [CrossRef]

22. Russell, S.J.; Norvig, P. Artificial Intelligence: A Modern Approach, 3rd ed.; Prentice-Hall, Inc.: Upper Saddle River, NJ, USA, 2009.

23. Mellit, A.; Kalogirou, S.A. Artificial intelligence techniques for photovoltaic applications: A review. Prog. Energy Combust. Sci. 2008, 34, 574-632. [CrossRef]

24. Dolara, A.; Grimaccia, F.; Leva, S.; Mussetta, M.; Ogliari, E. A physical hybrid artificial neural network for short term forecasting of PV plant power output. Energies 2015, 8, 1138-1153. [CrossRef]

25. Bouzerdoum, M.; Mellit, A.; Massi Pavan, A. A hybrid model (SARIMA-SVM) for short-term power forecasting of a small-scale grid-connected photovoltaic plant. Sol. Energy 2013, 98, 226-235. [CrossRef]

26. Barbieri, F.; Rajakaruna, S.; Ghosh, A. Very short-term photovoltaic power forecasting with cloud modeling: A review. Renew. Sustain. Energy Rev. 2017, 75, 242-263. [CrossRef]

27. Ogliari, E.; Dolara, A.; Manzolini, G.; Leva, S. Physical and hybrid methods comparison for the day ahead PV output power forecast. Renew. Energy 2017, 113, 11-21. [CrossRef]

28. Das, U.K.; Tey, K.S.; Seyedmahmoudian, M.; Mekhilef, S.; Idris, M.Y.I.; Van Deventer, W.; Stojcevski, A. Forecasting of photovoltaic power generation and model optimization: A review. Renew. Sustain. Energy Rev. 2018, 81, 912-928. [CrossRef]

29. Sobri, S.; Koohi-Kamali, S.; Rahim, N.A. Solar photovoltaic generation forecasting methods: A review. Energy Convers. Manag. 2018, 156, 459-497. [CrossRef]

30. Akhter, M.N.; Mekhilef, S.; Mokhlis, H.; Shah, N.M. Review on forecasting of photovoltaic power generation based on machine learning and metaheuristic techniques. IET Renew. Power Gener. 2019, 13, 1009-1023. [CrossRef]

31. Rich, E.; Knight, K. Artificial Intelligence; McGraw-Hill: New York, NY, USA, 1996.

32. LeCun, Y.; Bengio, Y.; Hinton, G. Deep learning. Nature 2015, 521, 436. [CrossRef]

33. Arthur, S. Some Studies in Machine Learning Using the Game of Checkers. IBM J. 1959, 3, $211-229$.

34. Alpaydin, E. Machine Learning: The New AI; MIT Press: Cambridge, MA, USA, 2016.

35. Haykin, S.S. Neural Networks and Learning Machines; Prentice Hall: New York, NY, USA, 2009.

36. Goodfellow, I.; Bengio, Y.; Courville, A. Deep Learning; MIT Press: New York, NY, USA, 2016.

37. Nielsen, M.A. Neural Networks and Deep Learning, 1st ed.; Determination Press: San Francisco, CA, USA, 2015; Volume 25.

38. Hochreiter, S.; Schmidhuber, J. Long short-term memory. Neural Comput. 1997, 9, 1735-1780. [CrossRef]

39. Cho, K.; Van Merriënboer, B.; Gulcehre, C.; Bahdanau, D.; Bougares, F.; Schwenk, H.; Bengio, Y. Learning phrase representations using RNN encoder-decoder for statistical machine translation. arXiv 2014, arXiv:1406.1078.

40. Mellit, A.; Massi Pavan, A.; Lughi, V. Short-term forecasting of power production in a large-scale photovoltaic plant. Sol. Energy 2014, 105, 401-413. [CrossRef]

41. Mellit, A.; Massi Pavan, A. A 24-h forecast of solar irradiance using artificial neural network: Application for performance prediction of a grid-connected PV plant at Trieste, Italy. Sol. Energy 2010, 84, 807-821. [CrossRef]

42. Chen, C.; Duan, S.; Cai, T.; Liu, B. Online 24-h solar power forecasting based on weather type classification using artificial neural network. Sol. Energy 2011, 85, 2856-2870. [CrossRef]

43. Shi, J.; Lee, W.J.; Liu, Y.; Yang, Y.; Wang, P. Forecasting power output of photovoltaic systems based on weather classification and support vector machines. IEEE Trans. Ind. Appl. 2012, 48, 1064-1069. [CrossRef]

44. Fernandez-Jimenez, L.A.; Muñoz-Jimenez, A.; Falces, A.; Mendoza-Villena, M.; Garcia-Garrido, E.; Lara-Santillan, P.M.; Zorzano-Santamaria, P.J. Short-term power forecasting system for photovoltaic plants. Renew. Energy 2012, 44, 311-317. [CrossRef]

45. Izgi, E.; Öztopal, A.; Yerli, B.; Kaymak, M.K.; Şahin, A.D. Short-mid-term solar power prediction by using artificial neural networks. Sol. Energy 2012, 86, 725-733. [CrossRef] 
46. Da Silva Fonseca, J.G., Jr.; Oozeki, T.; Takashima, T.; Koshimizu, G.; Uchida, Y.; Ogimoto, K. Use of support vector regression and numerically predicted cloudiness to forecast power output of a photovoltaic power plant in Kitakyushu, Japan. Prog. Photovolt. Res. Appl. 2012, 20, 874-882. [CrossRef]

47. Zeng, J.; Qiao, W. Short-term solar power prediction using a support vector machine. Renew. Energy 2013, 52, 118-127. [CrossRef]

48. De Giorgi, M.G.; Congedo, P.M.; Malvoni, M. Photovoltaic power forecasting using statistical methods: Impact of weather data. IET Sci. Meas. Technol. 2014, 8, 90-97. [CrossRef]

49. Almonacid, F.; Pérez-Higueras, P.J.; Fernández, E.F.; Hontoria, L. A methodology based on dynamic artificial neural network for short-term forecasting of the power output of a PV generator. Energy Convers. Manag. 2014, 85, 389-398. [CrossRef]

50. Liu, J.; Fang, W.; Zhang, X.; Yang, C. An improved photovoltaic power forecasting model with the assistance of aerosol index data. IEEE Trans. Sustain. Energy 2015, 6, 434-442. [CrossRef]

51. Gigoni, L.; Betti, A.; Crisostomi, E.; Franco, A.; Tucci, M.; Bizzarri, F.; Mucci, D. Day-ahead hourly forecasting of power generation from photovoltaic plants. IEEE Trans. Sustain. Energy 2017, 9, 831-842. [CrossRef]

52. Zhang, Y.; Beaudin, M.; Taheri, R.; Zareipour, H.; Wood, D. Day-ahead power output forecasting for small-scale solar photovoltaic electricity generators. IEEE Trans. Smart Grid 2015, 6, 2253-2262. [CrossRef]

53. Ehsan, R.M.; Simon, S.P.; Venkateswaran, P.R. Day-ahead forecasting of solar photovoltaic output power using multilayer perceptron. Neural Comput. Appl. 2017, 28, 3981-3992. [CrossRef]

54. Baharin, K.A.; Abdul Rahman, H.; Hassan, M.Y.; Gan, C.K. Short-term forecasting of solar photovoltaic output power for tropical climate using ground-based measurement data. J. Renew. Sustain. Energy 2016, 8, 053701. [CrossRef]

55. Pierro, M.; Bucci, F.; De Felice, M.; Maggioni, E.; Moser, D.; Perotto, A.; Cornaro, C. Multi-Model Ensemble for day ahead prediction of photovoltaic power generation. Sol. Energy 2016, 134, 132-146. [CrossRef]

56. Li, Z.; Rahman, S.M.; Vega, R.; Dong, B. A hierarchical approach using machine learning methods in solar photovoltaic energy production forecasting. Energies 2016, 9, 55. [CrossRef]

57. Paulescu, M.; Brabec, M.; Boata, R.; Badescu, V. Structured, physically inspired (gray box) models versus black box modeling for forecasting the output power of photovoltaic plants. Energy 2017, 121, 792-802. [CrossRef]

58. Liu, F.; Li, R.; Li, Y.; Yan, R.; Saha, T. Takagi-Sugeno fuzzy model-based approach considering multiple weather factors for the photovoltaic power short-term forecasting. IET Renew. Power Gener. 2017, 11, 1281-1287. [CrossRef]

59. Das, U.; Tey, K.; Seyedmahmoudian, M.; Idna Idris, M.; Mekhilef, S.; Horan, B.; Stojcevski, A. SVR-based model to forecast PV power generation under different weather conditions. Energies 2017, 10, 876. [CrossRef]

60. Leva, S.; Dolara, A.; Grimaccia, F.; Mussetta, M.; Ogliari, E. Analysis and validation of 24 hours ahead neural network forecasting of photovoltaic output power. Math. Comput. Simul. 2017, 131, 88-100. [CrossRef]

61. Pierro, M.; De Felice, M.; Maggioni, E.; Moser, D.; Perotto, A.; Spada, F.; Cornaro, C. Data-driven upscaling methods for regional photovoltaic power estimation and forecast using satellite and numerical weather prediction data. Sol. Energy 2017, 158, 1026-1038. [CrossRef]

62. Liu, W.; Liu, C.; Lin, Y.; Ma, L.; Xiong, F.; Li, J. Ultra-short-term forecast of photovoltaic output power under fog and haze weather. Energies 2018, 11, 528.

63. Al-Dahidi, S.; Ayadi, O.; Adeeb, J.; Alrbai, M.; Qawasmeh, B. Extreme Learning Machines for Solar Photovoltaic Power Predictions. Energies 2018, 11, 2725. [CrossRef]

64. Yao, X.; Wang, Z.; Zhang, H. A novel photovoltaic power forecasting model based on echo state network. Neurocomputing 2019, 325, 182-189. [CrossRef]

65. Han, Y.; Wang, N.; Ma, M.; Zhou, H.; Dai, S.; Zhu, H. A PV power interval forecasting based on seasonal model and nonparametric estimation algorithm. Sol. Energy 2019, 184, 515-526. [CrossRef]

66. Abdel-Nasser, M.; Mahmoud, K. Accurate photovoltaic power forecasting models using deep LSTM-RNN. Neural Comput. Appl. 2017, 31, 2727-2740. [CrossRef]

67. Son, J.; Park, Y.; Lee, J.; Kim, H. Sensorless PV power forecasting in grid-connected buildings through deep learning. Sensors 2018, 18, 2529. [CrossRef]

68. Wang, K.; Qi, X.; Liu, H. A comparison of day-ahead photovoltaic power forecasting models based on deep learning neural network. Appl. Energy 2019, 251, 113315. [CrossRef] 
69. Lee, D.; Kim, K. Recurrent neural network-based hourly prediction of photovoltaic power output using meteorological information. Energies 2019, 12, 215. [CrossRef]

70. Pedro, H.T.; Coimbra, C.F. Assessment of forecasting techniques for solar power production with no exogenous inputs. Sol. Energy 2012, 86, 2017-2028. [CrossRef]

71. Ogliari, E.; Grimaccia, F.; Leva, S.; Mussetta, M. Hybrid predictive models for accurate forecasting in PV systems. Energies 2013, 6, 1918-1929. [CrossRef]

72. Yona, A.; Senjyu, T.; Funabashi, T.; Kim, C.H. Determination method of insolation prediction with fuzzy and applying neural network for long-term ahead PV power output correction. IEEE Trans. Sustain. Energy 2013, 4, 527-533. [CrossRef]

73. Chu, Y.; Urquhart, B.; Gohari, S.M.; Pedro, H.T.; Kleissl, J.; Coimbra, C.F. Short-term reforecasting of power output from a 48 MWe solar PV plant. Sol. Energy 2019, 112, 68-77. [CrossRef]

74. Huang, C.M.; Chen, S.J.; Yang, S.P.; Kuo, C.J. One-day-ahead hourly forecasting for photovoltaic power generation using an intelligent method with weather-based forecasting models. IET Gener. Transm. Distrib. 2015, 9, 1874-1882. [CrossRef]

75. Wang, H.; Yi, H.; Peng, J.; Wang, G.; Liu, Y.; Jiang, H.; Liu, W. Deterministic and probabilistic forecasting of photovoltaic power based on deep convolutional neural network. Energy Convers. Manag. 2019, 153, 409-422. [CrossRef]

76. Dolara, A.; Grimaccia, F.; Leva, S.; Mussetta, M.; Ogliari, E. Comparison of training approaches for photovoltaic forecasts by means of machine learning. Appl. Sci. 2018, 8, 228. [CrossRef]

77. Behera, M.K.; Majumder, I.; Nayak, N. Solar photovoltaic power forecasting using optimized modified extreme learning machine technique. Eng. Sci. Technol. Int. J. 2019, 21, 428-438. [CrossRef]

78. Cervone, G.; Clemente-Harding, L.; Alessandrini, S.; Delle Monache, L. Short-term photovoltaic power forecasting using Artificial Neural Networks and an Analog Ensemble. Renew. Energy 2017, 108, 274-286. [CrossRef]

79. Ogliari, E.; Niccolai, A.; Leva, S.; Zich, R. Computational intelligence techniques applied to the day ahead PV output power forecast: PHANN, SNO and mixed. Energies 2019, 11, 1487. [CrossRef]

80. Nespoli, A.; Ogliari, E.; Dolara, A.; Grimaccia, F.; Leva, S.; Mussetta, M. Validation of ANN training approaches for day-ahead photovoltaic forecasts. In Proceedings of the International Joint Conference on Neural Networks (IJCNN), Rio de Janeiro, Brazil, 8-13 June 2018.

81. Zang, H.; Cheng, L.; Ding, T.; Cheung, K.W.; Liang, Z.; Wei, Z.; Sun, G. Hybrid method for short-term photovoltaic power forecasting based on deep convolutional neural network. IET Gener. Transm. Distrib. 2018, 12, 4557-4567. [CrossRef]

82. Eseye, A.T.; Zhang, J.; Zheng, D. Short-term photovoltaic solar power forecasting using a hybrid Wavelet-PSO-SVM model based on SCADA and Meteorological information. Renew. Energy 2019, 118, 357-367. [CrossRef]

83. VanDeventer, W.; Jamei, E.; Thirunavukkarasu, G.S.; Seyedmahmoudian, M.; Soon, T.K.; Horan, B.; Stojcevski, A. Short-term PV power forecasting using hybrid GASVM technique. Renew. Energy 2019, 140, 367-379. [CrossRef]

84. Gao, M.; Li, J.; Hong, F.; Long, D. Day-ahead power forecasting in a large-scale photovoltaic plant based on weather classification using LSTM. Energy 2019, 187, 115838. [CrossRef]

85. Ospina, J.; Newaz, A.; Faruque, M.O. Forecasting of PV plant output using hybrid wavelet-based LSTM-DNN structure model. IET Renew. Power Gener. 2019, 13, 1087-1095. [CrossRef]

(C) 2020 by the authors. Licensee MDPI, Basel, Switzerland. This article is an open access article distributed under the terms and conditions of the Creative Commons Attribution (CC BY) license (http://creativecommons.org/licenses/by/4.0/). 